\title{
THE DEPARTMENT OF PEOPLE'S COMMISSARIAT OF JUSTICE OF THE RSFSR IN THE STALINGRAD REGION: FEATURES OF FUNCTIONING BEFORE AND DURING THE BATTLE OF STALINGRAD
}

\author{
Svetlana Yu. Pishchulina \\ International Law Institute (Volzhsky Branch), Volzhsky, Volgograd region, Russian Federation \\ Marina L. Davydova \\ Volgograd State University, Volgograd, Russian Federation \\ Aleksandr A. Vilkov \\ Saratov State University named after N. G. Chernyshevsky, Saratov, Russian Federation
}

\begin{abstract}
The paper shows the main areas of work of the Department of justice in the Stalingrad region of the People's Commissariat of Justice of the RSFSR in 1941-1942. These included the restructuring of the activities of the Department to the emergency regime, manpower policy, synthesis and analysis of judicial practice according to the Decrees of the Presidium of the Supreme Soviet of the USSR to strengthen labour discipline at enterprises, collective farms and state farms, to fight against speculation, embezzlement of socialist property, the failure of defense measures - blackout, passport regime, non-payment of fines and duties, taxation of public supplies. The research relevance is associated with the lack of works devoted to the People's Courts in the period of the Great Patriotic War in the modern historiography. The Stalingrad region is illustrative in this aspect, since during the war it represented rear, frontline and front areas. It is noted that in the conditions of the rear region, the Department of People's Commissariat for Justice and the people's courts of the Stalingrad region performed their activities on a relatively stable basis. The directives and explanatory guidelines of the Department of People's Commissariat for Justice of the USSR and the RSFSR were timely and helped toreorganize the work of the Department. In 1942 in the situation at the frontline and front areas the activities of the Department of People's Commissariat for Justice and people's courts was hampered. The evacuation led to a reduction in the number of judicial districts, separation of judicial practice from existing laws because of the lack of timely codification and the special literature. The Battle of Stalingrad caused the significant damage to the Department, both material and personnel. In 1943 $\infty$ the Department of People's Commissariat for Justice was forced to start its activities with organizational issues.

Key words: Stalingrad, war, justice, courts, discipline, defense, public order.

Citation. Pishchulina S.Yu., Davydova M.L., Vilkov A.A. The Department of People's Commissariat of Justice of the RSFSR in the Stalingrad Region: Features of Functioning before and during the Battle of Stalingrad. Vestnik Volgogradskogo gosudarstvennogo universiteta. Seriya 4, Istoriya. Regionovedenie. Mezhdunarodnye otnosheniya [Science Journal of Volgograd State University. History. Area Studies. International Relations], 2018, vol. 23, no. 1, pp. 56-66. (in Russian). DOI: https://doi.org/10.15688/jvolsu4.2018.1.6

\section{УПРАВЛЕНИЕ НАРКОМАТА ЮСТИЦИИ РСФСР} ПО СТАЛИНГРАДСКОЙ ОБЛАСТИ: ОСОБЕННОСТИ ФУНКЦИОНИРОВАНИЯ НАКАНУНЕ И В ПЕРИОД СТАЛИНГРАДСКОЙ БИТВЫ
\end{abstract}

\author{
Светлана Юрьевна Пищулина
}

Международный юридический институт (Волжский филиал), г. Волжский, Российская Федерация 
Управление Наркомата юстиции РСФСР по Сталинградской области: особенности функционирования

\section{Марина Леонидовна Давыдова}

Волгоградский государственный университет, г. Волгоград, Российская Федерация

\section{Александр Алексеевич Вилков}

Саратовский государственный университет им. Н.Г. Чернышевского, г. Саратов, Российская Федерация

Аннотация. В статье показаны основные направления работы Управления юстиции по Сталинградской области Наркомата юстиции РСФСР в 1941-1942 годах. К ним относились перестройка деятельности Управления на чрезвычайный режим работы, решение кадровых вопросов, обобщение и анализ судебной практики по Указам Президиума Верховного Совета СССР по укреплению трудовой дисциплины на предприятиях, в колхозах и совхозах, по борьбе со спекуляцией, расхищением социалистической собственности, невыполнением оборонных мероприятий - светомаскировки, паспортного режима, невыплатой штрафов и пени по сборам, самообложению, государственным поставкам. Актуальность поднятой проблемы обусловлена отсутствием в современной историографии трудов, посвященных народным судам в период Великой Отечественной войны. Сталинградская область в данном аспекте показательна, так как в годы войны была и тылом, и прифронтовым, и фронтовым регионом. Отмечено, что в условиях тылового региона УНКЮ и народные суды Сталинградской области работали относительно стабильно. Директивы и разъяснительные указания НКЮ СССР и РСФСР поступали своевременно и существенно помогали реорганизовать работу Управления. В 1942 г. в обстановке прифронтовой и фронтовой местности деятельность УНКЮ и народных судов была затруднена. Эвакуация привела к сокращению количества судебных участков, отрыву судебной практики от действующих законов из-за отсутствия своевременной кодификации и специальной литературы. Сталинградская битва нанесла Управлению существенный ущерб, как в материальном плане, так и в кадровом составе. В 1943 г. УНКЮ вынуждено было начинать свою деятельность с организационных вопросов.

Методика исследования была разработана М.Л. Давыдовой. Историографическая и источниковая база публикации готовилась А.А. Вилковым. Анализ источников и их интерпретация осуществлялись С.Ю. Пищулиной.

Ключевые слова: Сталинград, война, юстиция, суды, дисциплина, оборона, общественный порядок.

Цитирование. Пищулина С. Ю., Давыдова М. Л., Вилков А. А. Управление Наркомата юстиции РСФСР по Сталинградской области: особенности функционирования накануне и в период Сталинградской битвы // Вестник Волгоградского государственного университета. Серия 4, История. Регионоведение. Международные отношения. - 2018. - Т. 23, № 1. - С. 56-66. - DOI: https://doi.org/10.15688/jvolsu4.2018.1.6

Масштабное сражение советских и немецко-фашистских войск под Сталинградом вызывает интерес ученых уже более семидесяти лет. Значительна историография проблемы восстановления города и области после окончания битвы на Волге [20]. Тем не менее о деятельности в годы Великой Отечественной войны Управления юстиции по Сталинградской области Наркомата юстиции РСФСР (далее - УНКЮ по Сталинградской области НКЮ РСФСР) практически нет нигде даже отдельных упоминаний.

Актуальность поднятой темы обусловливается также и тем, что военная юстиция в публикациях авторов, занимающихся указанной проблематикой, зачастую ограничивается раскрытием специфики работы военных трибуналов, народные суды остаются за границами исследования. Управления юстиции как раз контролировали и оказывали юриди- ческую и практическую помощь именно народным судам в сложных, быстроизменяющихся условиях военных действий. В этом плане показательна деятельность УНКЮ по Сталинградской области, так как регион за период войны был и тыловым, и прифронтовым, и фронтовым, и восстанавливающимся.

Материалы фонда 6332 Управления МВД по Сталинградской области Государственного архива Волгоградской области сохранили распорядительные, отчетные, делопроизводственные документы наркоматов СССР и РСФСР, областного управления, на основании которых можно определить особенности функционирования народных судов, судебных приставов, нотариальных контор, коллегии адвокатов и юридических консультаций на разных этапах Великой Отечественной войны. Анализы судебной практики по годам, статистические отчеты и обзоры УНКЮ о движении 


\section{СТАЛИНГРАДСКИЙ ТЫЛ}

гражданских дел, исполнительного производства дают возможность определить, каким образом внедрялись в повседневную жизнь советских граждан «законы военного времени», особенно Указы Президиума Верховного Совета СССР (далее - ПВС СССР) о трудовой дисциплине, госпоставках, самообложении и пр. Народные суды в военный период реагировали на изменения потребностей государства одними из первых, так как работали на укрепление тыла и, по возможности, морального духа бойцов Красной Армии, обеспечивая соблюдение законности для членов их семей.

Методологической основой исследования являются принципы историзма и объективности. Применялись традиционные для исторического исследования методы. С помощью конкретно-исторического метода прослежены процессы перестройки народных судов к нуждам военного времени. Системно-структурный метод помог выделить и проанализировать основные направления деятельности УНКЮ по Сталинградской области. Сравнительно-исторический метод использовался при установлении способов реагирования нарсудов на потребности государства в годы войны, раскрыл социальные проблемы региона на определенном этапе развития военной ситуации.

27 мая 1939 г. Сталинградский областной исполнительный комитет Совета народных депутатов принял постановление об образовании Управления юстиции по Сталинградской области в соответствии с Указом Верховного Совета РСФСР для оказания помощи судебным органам и контроля над ними [14, л. 15]. Начавшаяся через два года Великая Отечественная война изменила режим функционирования наркоматов юстиции СССР и РСФСР, региональных управлений.

В июне - июле 1941 г. был издан ряд директивных указаний, который оформил перевод системы народных судов для работы в чрезвычайных условиях. Определялся порядок замещения мобилизованных судей, отменялись отпуска [1, л. 134-135], сокращалось количество судебных участков в сельской местности на $20 \%$, в городах на $25 \%$, их новое штатное расписание к 1 августу фиксировалось в наркомате финансов [13, л. 155-156], расширялись процессуальные полномочия судей в подготовительных заседаниях по маловажным и административным производствам, ограничивался вызов в суд с отрывом от производства народных заседателей, свидетелей, экспертов [15, л. 142-146], оговаривались условия прекращения нерассмотренных дел, прописывались правила заочных процессов при наличии личного признания обвиняемого или изобличающих его показаний свидетелей [18, л. 147-149], приостанавливались незаконченные дела и исполнение решений о выселении из домов/квартир лиц, призванных в Красную Армию, и членов их семей [15, л. 142-146]. Одной из важнейших целей судебного процесса было объявлено установление мотивов совершения преступления. При подозрении на уклонение от мобилизации в Красную Армию (трактовалось как дезертирство) дело передавалось на доследование или сразу в военный трибунал. В связи с образовавшимися кадровыми проблемами судебные исполнители получили право обслуживать два участка за дополнительное вознаграждение до $50 \%$ к окладу [15, л. 142-146].

Изменения коснулись подсудности областных и народных судов. 17 июля 1941 г. НКЮ СССР приказом № 030с к ведению облсуда отнес споры между государственными, кооперативными, общественными организациями, если хотя бы одно из них выполняло военный заказ; о признании авторских прав; о нарушении техники безопасности. Народные суды в отношении военно-промышленных предприятий вели дела закрытым заседанием и секретным производством. При этом списки оборонных заводов уничтожались, их перечень судьи должны были знать устно [16, л. 157-157 об.].

Таким образом, к середине августа 1941 г. комплекс первичных мероприятий был документально закреплен, начался процесс перестройки работы народных судов и региональных Управлений юстиции на «военные рельсы».

Первый год Великой Отечественной войны отличался трудностями не только на фронтах, повседневная жизнь советских граждан претерпела значительные перемены. В действие были введены «законы военного времени», которые не отменяли, а ужесточали и дополняли кодифицированные акты советско- 
го государства. Особое внимание наркоматы юстиции СССР и РСФСР уделяли анализу судебной практики по таким составам, как спекуляция, нарушение правил торговли, растраты, хищения, невыполнение мероприятий оборонного порядка, нарушение Указов Президиума Верховного Совета СССР (далее ПВС СССР) от 10 июля 1940 г. и 10 февраля 1941 г. (дезертирство с предприятий, самовольное оставление рабочего места). В условиях введения карточной системы распределения продуктов и острого дефицита рабочих рук эти преступления были признаны наиболее социально и экономически опасными.

Позже к данному перечню добавилось невыполнение требований государственной санинспекции - некачественная организация санитарной охраны водопроводов и источников водоснабжения, срыв мероприятий по обеспечению доброкачественности продуктов, по предупреждению возникновения заразных мероприятий [17, л. 168-169]. Тыл должен был бесперебойно обеспечивать нужды воюющей страны, поэтому имеющийся опыт вынуждал властные структуры контролировать безопасность снабжения населения продуктами первой необходимости.

Ситуация в стране, когда шло стремительное отступление Красной Армии по всем фронтам, эвакуация большого потока населения, заводов, фабрик, колхозов и совхозов, стимулировала исполнительные органы на быстрый и эффективный поиск новых моделей управления. С этой целью уже в сентябре 1941 г. НКЮ РСФСР подготовил информационное сообщение региональным управлениям, в котором обобщил накопившийся опыт. Было рекомендовано вместо мобилизованных и отозванных в военные трибуналы судей-мужчин активнее привлекать женщин, укреплять сотрудничество с советскими и партийными учреждениями, повысить контроль над этапированием заключенных и розыском бежавших преступников. Особое волнение в НКЮ РСФСР вызывало прекращение нарсудами дел, связанных с применением норм Указа ПВС СССР от 16 июня 1940 года. Формулировки «невыполнение предприятиями условий найма», «не создано необходимых условий работы» в период военного времени запрещалось применять для оправдания обвиняемых [10, л. 196].
Сталинградское Управление НКЮ РСФСР до октября 1942 г. возглавлял В.С. Козлов. В штатном расписании числились заместители начальника, члены секретариата, бухгалтерии, финансово-хозяйственного сектора, инспектора спецчасти, статистического сектора, ревизор по нотариату и адвокатуре (они находились под рекомендательным контролем НКЮ), ревизоры судов, консультантыкодификаторы.

Дважды в месяц Управление обязывалось предоставлять в наркомат юстиции РСФСР статистическую отчетность о своей деятельности. На особом контроле оставались контрреволюционные преступления (статья 58 УК РСФСР 1926 г.), невыполнение повинностей и общественных заданий, ненадлежащее хранение хлеба и других сельскохозяйственных продуктов [22, л. 227]. Появились новые составы преступлений, к примеру, побеги из специальных строительных рабочих колонн квалифицировались по статье 59-6 УК РСФСР 1926 г.; за другие составы преступлений изменилась мера наказания: так, пропаганда и агитация против советской власти судами рассматривались теперь по статье 58-10, самогоноварение - по статьям 102 и 103 УК РСФСР 1926 г. [22, л. 228].

Особенно обширной стала практика нарсудов по самовольному оставлению учащимися школ фабрично-заводского обучения (далее - ФЗО) и ремесленных училищ (далее РУ). УНКЮ даже советовал судьям в связи со значительным ростом такого рода дел рекомендовать дирекции школ и училищ изначально извещать молодых людей о том, что отказ от учебы приравнивался к дезертирству, и их ожидало наказание по указу ПВС СССР от 28 декабря 1940 г. [22, л. 194].

Сталинград оставался тыловым городом весь 1941 год. В этот период УНКЮ и подконтрольные ему учреждения функционировали в относительно стабильном режиме. Кадровый голод начинал сказываться на составе судей народных судов, адвокатуре (отсюда шло восполнение судейского состава), судебных исполнителей. В судебной практике отмечался рост дел особого производства (главным образом за счет нарушений правил оборонных мероприятий, прежде всего светомаскировки, паспортного режима, правил дежур- 


\section{СТАЛИНГРАДСКИЙ ТЫЛ}

ства около домов, общественного порядка, санитарии, торговли, военного учета, противопожарных мероприятий, борьбе с безнадзорностью детей [6, л. 2-3]) по Указам ПВС СССР от 10 июля 1940 г., 10 февраля 1941 г., 28 декабря 1941 г., о спекуляции. Это соответствовало общегосударственной тенденции.

В 1942 г. по штатному расписанию НКЮ РСФСР в области значилось 112 судебных участков, из них действовало 107. За период до 1 июля 1942 г. ими было разобрано 19000 уголовных и 29000 гражданских дел [9, л. 53].

Ситуация в стране становилась все более сложной. Государство требовало от населения самоотверженной борьбы на фронтах и в тылу. Возрос контроль наркомата юстиции РСФСР за делами и исполнением приговоров по самовольному уходу рабочих с предприятий и нарушению трудовой дисциплины. Вышло несколько приказов, в которых подробно анализировались недостатки и предлагались меры по их искоренению. Главным образом обращалось внимание на факт отправки приговоров судьями в органы милиции без дальнейшего получения подтверждений их исполнения. Милиция ограничивалась формальным розыском осужденных, наводя справки через адресные столы и по последнему месту жительства, при отрицательном результате объявлялся всесоюзный розыск.

Сталинградское Управление организовало проверку народных судов. Было выявлено, что на 1 мая 1942 г. по 48 участкам числилось 1087 неисполненных приговоров подобного рода, в том числе за 1941 г. - 659, за 1942 г. - 357, из них 87 \% по городу. Положительный опыт контроля за исполнением приговоров отмечался в Дубовском, Камышинском, Эрленбахском и Молотовском районах, к числу отстающих отнесены Нижне-Добринский, Краснооктябрьский, Даниловский, Дзержинский, Лемешковский, Красноармейский [7, л. 14-19].

Анализ судебной практики и организованная в июне дополнительная ревизия показали, что количество дел по нарушителям Указов ПВС СССР от 26 июня 1940 г. увеличивается. Основными категориями обвиняемых являлись кадровые рабочие промышленных предприятий и молодые рабочие в возрасте от 16 до 25 лет. При этом установлено, что администрация заводов часто произвольно трактовала понятие «самовольный уход». Так, из 1329 дел, разобранных в I квартале 1942 г., по данному составу обнаружено 540 опозданий, 310 невыходов на работу, 66 человек спало на работе, 5 явилось в пьяном виде, 19 «бездельничало», 36 отказались от сверхурочных, двое не вышли на работу в связи с круглосуточным дежурством, 33 имело иные причины, не связанные с переходом/отъездом в иные места [5, л. 30-49]. Только 318 человек осуждено за самовольный уход. Надо отметить, что нарсуды часто в этот период выносили приговоры в заочном заседании, поэтому часть из них обжаловалась. По рассматриваемому составу только $2,8 \%$ приговоров отменено, что говорит о продолжении заложенной в 1941 г. тенденции на ужесточение наказаний за нарушение трудовой дисциплины. При установлении причин совершения правонарушений, особенно молодыми людьми, на первом месте продолжали оставаться бытовые мотивы: администрации предприятий не могли организовать продажу хлеба, отпуск завтраков, очередность выходных дней и т. п. Изза этих неурядиц приходилось либо опаздывать на работу, либо оставаться без продуктов первой необходимости. Тем не менее в приговорах с 1942 г. эти факты не фигурировали. Укрепляя сотрудничество с местными управленческими структурами, судьи могли самостоятельно решать вопрос о передаче информации о мотивах трудовой преступности в дирекцию, в обком ВКП(б), в прокуратуру [5, л. 35-36, 49]. Цель информирования состояла в ликвидации предпосылок к совершению правонарушений и улучшении работы военно-промышленного комплекса.

Важной особенностью 1942 г. стало возникновение дел, связанных с процессами эвакуации. Например, 112 эвакуированных из Одесского детского дома детей было размещено в комнате, рассчитанной на 20 человек, при этом малыши оставлены без еды. Судья областного суда Н.А. Миронов приговорил ответственных лиц к 6 месяцам исправительно-трудовых работ, однако НКЮ РСФСР посчитал данное решение либеральным [9, л. 53].

Нарушение правил техники безопасности на предприятиях, светомаскировки, воровство и расхищение социалистической соб- 
ственности, «разбазаривание» продуктовых и промышленных товаров в магазинах, складах, детских домах являлись значительной частью судебной практики народных судов в первой половине 1942 года. В гражданском производстве отмечалась наибольшая задержка сроков рассмотрения. Недостаток квалифицированных судей-цивилистов, который стал ощущаться все острее, мешал правильно квалифицировать сложные дела и разбираться в новом законодательстве, допускалось много ошибок, и практически на каждую тысячу опротестованных дел около 50 \% решений Верховный Суд отменял [9, л. 54].

Существенным направлениям деятельности сельских нарсудов оставались дела по взысканию недоимок и пеней. Здесь судьи нередко допускали процессуальные промахи: вместо денежных штрафов в тройном размере разрешали оплату натуральным продуктом, причем непосредственно районному уполномоченному наркомата по заготовкам. В протоколах заседаний процессуальные действия отражались не полностью, исполнительные листы вручались ответчикам не сразу. УНКЮ несколько раз проводило совещания с целью искоренения недочетов, однако эффективных обратных действий со стороны сельских нарсудов не последовало [3, л. 102-121].

15 апреля 1942 г. издан Указ ПВС СССР о минимуме трудодней колхозников и о мобилизации населения на сельскохозяйственные работы. В ходе проверки УНКЮ, организованной в августе 1942 г., установлено, что процедура подсчета трудовых дней в колхозах и совхозах велась неграмотно. Это часто приводило к подаче необоснованных исков против единоличников и освобожденных лиц. Процессы, связанные с мобилизаций на сельхозработы и невыполнением минимума трудодней, было решено проводить в выездных заседаниях на местах. Основная масса обвиняемых состояла из женщин в возрасте от 30 до 50 лет, они трудились на своем приусадебном участке, чтобы обеспечить семью и выплатить налоги государству. Поэтому судьям приходилось не только рассматривать конфликтные ситуации, но и вести разъяснительную работу [2, л. 123-132].

Стержневой проблемой 1942 г. для Сталинградской области стал кадровый вопрос.
За IV квартал 1941 г. и I квартал 1942 г. по области состав судебных исполнителей обновлен более чем на $100 \%$, в связи с чем снизился сбор штрафов до 43,18 \%, исполнение решений судов [6, л. 8-9]. Для исправления ситуации были созданы специальные бригады из лучших судебных исполнителей. Это помогло завершить больше половины незаконченных исполпроизводств [9, л. 56-57].

Дефицит кадров наложил отпечаток на работу нотариальных контор и Сталинградской коллегии адвокатов. Нотариальные конторы закрывались. Часть сельских районов оставались неукомплектованными адвокатами, что мешало прокурорам участвовать в судебных заседаниях. Еще в 1941 г. НКЮ СССР среди недостатков коллегий адвокатов отметил, что освоение методики защиты подсудимых, ведения упрощенной кодификации новых актов, разбор казусов опытными адвокатами не передавались молодым кадрам [19, л. 224 - 225]. В 1942 г. эти недостатки ликвидированы не были, указания УНКЮ игнорировались [9, л. 56].

Таким образом, накануне Сталинградской битвы деятельность УНКЮ перестраивалась на чрезвычайный режим. Количество дел на одного судью возрастало. Основу практики составляли дела по Указам ПВС СССР об укреплении трудовой дисциплины. Все больше выявлялось процессуальных неточностей, возникавших из-за использования устаревшего законодательства. Кодификационный отдел Управления и коллегии адвокатов не справлялись с возросшим объемом работы по «законам военного времени».

В августе 1942 г. началась эвакуация судов из задонских районов - Кагановического, Котельниковского, Клетского, Серафимовичского. Количество судебных участков сокращалось. Сотрудники УНКЮ и судов, судебные приставы, нотариусы, адвокаты все активнее наравне с другими жителями стали привлекаться к оборонительному строительству. 25 августа УНКЮ эвакуировалось на левый берег Волги, до 1 сентября оно располагалось в Средней Ахтубе, Ленинске, Старой Полтавке. Аппарат Управления прибыл на новое место не в полном составе, из 27 штатных единиц осталось только 9. В октябре 1942 г. УНКЮ вновь перебазировался в Ни- 


\section{СТАЛИНГРАДСКИЙ ТЫЛ}

колаевку. В связи с болезнью В.С. Козлова длительное время Управление не имело руководителя, исполняли обязанности начальника судья областного суда Н.А. Миронов, потом С.3. Левин.

Удалось спасти часть имущества - наряды с некоторыми директивами, секретное производство, личные дела народных судей, печать и штамп. Все остальное сгорело при бомбежках города немецко-фашистской авиацией.

Среди оставшегося штата УНКЮ произошло перераспределение полномочий: все прифронтовые районы обслуживала ревизор М.Ф. Переходнова, Сталинград - заместитель начальника УНКЮ П.А. Ардашев. Для оказания помощи нарсудам северо-западных районов области был образован второй центр Управления в Елани, куда были направлены два работника УНКЮ. Тем не менее с сельскими районами связь практически была потеряна, так как весь транспорт УНКЮ был мобилизован на нужды фронта [21, л. 139-141 об.].

Бои Красной Армии с немецко-фашистскими войсками весь период Сталинградской битвы отличались особым упорством с обеих сторон. Несмотря на то что регион стал фронтовым, работа УНКЮ продолжалась. Функционировали ревизорские группы, ими проконтролированы нарсуды в Хоперском, Алексеевском, Лемешковском, Руднянском районах.

Сталинградский областной суд сосредоточил свою деятельность на делах об уклонениях от выполнения повинностей в военное время. Всего с сентября по декабрь 1942 г. было рассмотрено 308 дел, из них только по Сталинграду было осуждено 30 человек. Анализ судебной практики по данному составу был очень противоречив. Диапазон наказаний осужденным колебался от штрафа в 3000 рублей и до 8-10 лет лишения свободы, так как уклонение от трудовой повинности могло квалифицироваться и по УК РСФСР 1926 г., и по Указам ПВС [4, л. 147-152 об.]. УНКЮ совместно с областным судом вырабатывало единую позицию по вопросу о наказаниях за это преступление.

В несколько раз возросла практика народных судов по делам о хищении хлеба в колхозах. Только за октябрь - ноябрь 1942 г. было осуждено 110 человек из 7 сельских рай- онов области [12, л. 153 об.]. В первую очередь это правонарушение вызывалось процессами эвакуации колхозного имущества, неразберихой и пропагандистскими слухами об отступлении советских войск.

Деятельность судов была затруднена также отсутствием специализированной литературы, кодексов, новых законов и их упрощенной кодификации. Поэтому судьи нередко выносили приговоры по утратившим силу законам. Отсутствовали бланки, делопроизводство и протоколы судебных заседаний, в том числе секретного производства, велись на газетах, газетной бумаге, обоях.

С освобождением районов Сталинградской области от оккупации остро встала проблема с подбором кадров, в первую очередь судей. Обком ВКП(б) принял решение о возвращении старых кадров к местам несения службы, однако данное постановление выполнить практически было не возможно. Поэтому УНКЮ изыскивались кадры из эвакуированного населения, опытных заседателей, секретарей судов, адвокатов. Так, в декабре 1942 г. для трех районов было подобрано двенадцать судей, еще девять районов оставались без судейского аппарата [11, л. 146].

После окончания битвы в регионе работало из 112 судебных участков 77, из них один в Кировском районе Сталинграда, из 19 нотариальных контор - 8. В 53 судебных участках трудились 68 адвокатов, ощущался недостаток еще 30 человек. УНКЮ имело трех ревизоров, старшего консультанта по кодификации, консультанта, инспектора по кадрам, трех бухгалтеров, заведующего секретариатом, двух машинисток. Остальных кадров не хватало [8, л. 157-158]. В 1943 г. Управление вынуждено было вновь начать свою деятельность с организационных вопросов.

В 1941-1942 гг. к основным направлениям деятельности УНКЮ по Сталинградской области НКЮ РСФСР следует отнести перестройку системы управления на чрезвычайный режим военного времени. Среди существенных мероприятий можно выделить оптимизацию работы судебных участков, решение кадрового вопроса путем привлечения на место мобилизованных и отозванных в военные трибуналы судей-мужчин женщин, наиболее опытных народных заседателей и секре- 
тарей судов, обобщение практики по делам о нарушении трудовой дисциплины на предприятиях, в колхозах и совхозах, по уголовным преступлениям, связанным со спекуляцией, хищениями социалистической собственности, нарушением оборонных установлений. В 1941 г. УНКЮ и народные суды Сталинградской области функционировали в относительно стабильной обстановке. В 1942 г. ситуация обострилась в связи с приближением линии фронта и ведением военных действий в регионе. УНКЮ потерял связь с рядом сельских судов, не велась кодификационная работа, затруднено было рассмотрение новых составов дел из-за отсутствия нормативной литературы. Тем не менее соблюдение социалистической законности оставалось главной задачей Управления.

\section{СПИСОК ЛИТЕРАТУРЫ}

1. Директива НКЮ РСФСР № М16/с от 23.06. 1941 о регулярном докладе количества призванных в Красную Армию судей и об их замещении на местах // Государственный архив Волгоградской области (далее - ГАВО). - Ф. 6332. - Оп. 1. - Д. 2. 240 л.

2. Доклад № 350 от 18.08.1942 о судебной практике народных судов Сталинградской области по делам о нарушителях Указа ПВС СССР от 15.04.1942 о минимуме трудодней колхозников и о мобилизации населения на сельхозработы // ГАВО. Ф. 6332. -Оп. 1. - Д. 4. - 160 л.

3. Доклад за № ОС-1 от 17.06.1942 об изучении судебной практики нарсудов Сталинградской области по делам особого производства о взыскании недоимок и пени по налогам, сборам, самообложению, недоимок по обязательным госпоставкам сельскохозяйственных продуктов и наложению штрафов // ГАВО. - Ф. 6332. - Оп. 1. - Д. 4. - 160 л.

4. Доклад о работе Сталинградского облсуда по делам, связанным с уклонениями от выполнения повинностей в военное время, декабрь 1942 г. // ГАВО. - Ф. 6332. - Оп. 1. - Д. 4. - 160 л.

5. Доклад от 22.06.1942 по изучению судебной практики нарсудов Сталинградской области по преступлениям по Указу ПВС СССР от 26.06.1940 // ГАВО. - Ф. 6332. - Оп. 1. - Д. 4. - 160 л.

6. Доклад по изучению судебной практики нарсудов Сталинградской области по делам особого производства - о взыскании штрафов, наложенных в административном порядке за 1 полугодие 1941 г. - январь - февраль 1942 г. // ГАВО. - Ф. 6332. Оп. 1. - Д. 4. -160 л.
7. Докладная записка № 188 от 16.05.1942 о получении приказа за контролем исполнения приговоров по делам лиц, осужденных за самовольный уход с предприятий и учреждений (по приказу НКЮ СССР № 05 от 06.03.1942)// ГАВО. - Ф. 6332. - Оп. 1. Д. $4 .-160$ л.

8. Докладная записка исполняющего обязанности начальника УНКЮ С.З. Левина в НКЮ РСФСР о состоянии работы УНКЮ от 20.12.1942 // ГАВО. Ф. 6332. - Оп. 1. - Д. 4. - 160 л.

9. Докладная записка старшего ревизора НКЮ РСФСР Е. Грина за № 303 от 01.07.1942 в Сталинградский обком ВКП(б) т. Ляпину о результатах проверки работы судебных органов Сталинградской области в 1942 г. // ГАВО. - Ф. 6332. - Оп. 1. Д. 4. -160 л.

10. Информационное письмо НКЮ РСФСР № 1 - 2/сд от 12.09.1941 о работе судов в военное время // ГАВО. - Ф. 6332. - ОП. 1. - Д. 2. - 240 л.

11. Информационное сообщение Уполномоченному КПК по Сталинградской области т. Ягодкину от временноисполняющего обязанности начальника УНКЮ Н.А. Миронова от 04.12.1942 // ГАВО. - Ф. 6332. - Оп. 1. - Д. 4. - 160 л.

12. Обобщение практики облсуда за октябрь ноябрь 1942 г. за № 437 от 04.12.1942 // ГАВО. Ф. 6332. -Оп. 1. - Д. 4. -160 л.

13. Письмо НКЮ СССР Рычкова за № 028с от 15.07.1941 о сокращении штатов в связи с военной обстановкой // ГАВО. - Ф. 6332. - Оп. 1. - Д. 2. 240 л.

14. Постановление Сталинградского областного исполнительного комитета Совета народных депутатов об образовании Управления юстиции НКЮ РСФСР // ГАВО. - Ф. 2115. - Оп. 1. - Д. 247. - Л. 15.

15. Приказ НКЮ РСФСР № 5/С от 07.07. 1941 г. о неотложных мероприятия органов НКЮ в военное время // ГАВО. - Ф. 6332. - ОП. 1. - Д. 2. - 240 л.

16. Приказ НКЮСССР №030с от 17 июля 1941 г. о подсудности дел // ГАВО. - Ф. 6332. - Оп. 1. Д. 2. -240 л.

17. Приказ Прокурора и НКЮ РСФСР №10/7c от 04.08.1941 об уголовной ответственности за невыполнение требований органов государственной санинспекции // ГАВО. - Ф. 6332. - Оп. 1. - Д. 2. 240 л.

18. Разъяснительное письмо № 023 НКЮ СССР Рычкова на места о делах судов в связи с эвакуацией от 08.07.1941 // ГАВО. - Ф. 6332. - Оп. 1. - Д. 2. 240 л.

19. Разъяснительное письмо НКЮ СССР за № 16-А от 19.09.1941 о недостатках в работе президиумов коллегий адвокатов // ГАВО. - Ф. 6332. Оп. 1. - Д. 2. - 240 л.

20. Редькина, О. Ю. Изучение истории Сталинградской битвы и восстановления Сталинграда в 


\section{СТАЛИНГРАДСКИЙ ТЫЛ}

Волгоградском государственном университете / О. Ю. Редькина // Вестник Волгоградского государственного университета. Серия 4. История. Регионоведение. Международные отношения. - 2013. № 1 (23). - C. 143-148. - DOI: http://dx.doi.org/ 10.15688/jvolsu4.2013.1.23.

21. Спецдонесение № 1/П/352 от 08.09.1942 // ГАВО. -Ф. 6332. - Оп. 1. - Д. 4. - 160 л.

22. Спецдонесения УНКЮ по Сталинградской области в НКЮ РСФСР со статистической отчетностью // ГАВО. - Ф. 6332. - Оп. 1. - Д. 2. - 240 л.

\section{REFERENCES}

1. Direktiva NKYu RSFSR№M16/s ot 23.06.1941 g. o regulyarnom doklade kolichestva prizvannykh $\mathrm{v}$ Krasnuyu Armiyu sudey i ob ikh zameshchenii na mestakh [Directive of People's Commissariat of Justice of the RSFSR no. M16/s of June 23, 1941 on the Regular Report of Judges Called Upon to the Red Army and on Their Replacement]. Gosudarstvennyy arkhiv Volgogradskoy oblasti [State Archive of the Volgograd Region], F. 6332, Op. 1, D. 2.2401.

2. Doklad № 350 ot 18.08.1942 o sudebnoy praktike narodnykh sudov Stalingradskoy oblasti po delam o narushitelyakh Ukaza PVS SSSR ot 15.04.1942 o minimume trudodney kolkhoznikov i o mobilizatsii naseleniya na selkhozraboty [Report no. 350 of August 18, 1942 on the Judicial Practice of People's Courts in the Stalingrad Region in Cases of Violators of the Decree of the USSR Supreme Soviet of April 15, 1942 on the Minimum of Farmers' Workdays and the Mobilization of the Population for Agricultural Works]. Gosudarstvennyy arkhiv Volgogradskoy oblasti [State Archive of the Volgograd Region], F. 6332, Op. 1, D. 4. 1601 .

3. Doklad za № OS-1 ot 17.06.1942 ob izuchenii sudebnoy praktiki narsudov Stalingradskoy oblasti po delam osobogo proizvodstva o vzyskanii nedoimok i peni po nalogam, sboram, samooblozheniyu, nedoimok po obyazatelnym gospostavkam selskokhozyaystvennykh produktov i nalozheniyu shtrafov [Report no. OS-1 of June 17, 1942 on the Study of Judicial Practice of People's Courts of the Stalingrad Region on Special Proceedings for the Recovery of Arrears and Penalties on Taxes, Duties, Self-Taxation, Debts on Obligatory State Deliveries of Agricultural Products and the Imposition of Fines]. Gosudarstvennyy arkhiv Volgogradskoy oblasti [State Archive of the Volgograd Region], F. 6332, Op. 1, D. $4,1601$.

4. Doklad o rabote Stalingradskogo oblsuda po delam, svyazannym s ukloneniyami ot vypolneniya povinnostey v voennoe vremya, dekabr $1942 \mathrm{~g}$. [Report on the Stalingrad Regional Court in the Cases of Evasion from Execution of Duties in Wartime,
December 1942]. Gosudarstvennyy arkhiv Volgogradskoy oblasti [State Archive of the Volgograd Region], F. 6332, Op. 1, D. 4. 1601.

5. Doklad ot 22.06.1942 po izucheniyu sudebnoy praktiki narsudov Stalingradskoy oblasti po prestupleniyam po Ukazu PVS SSSR ot 26.06.1940 [Report of June 22, 1942 on the Study of Judicial Practice of the People's Courts in the Stalingrad Region for Crimes under the Decree of the USSR Supreme Soviet of June 26, 1940]. Gosudarstvennyy arkhiv Volgogradskoy oblasti [State Archive of the Volgograd Region], F. 6332, Op. 1, D. 4. 1601.

6. Doklad po izucheniyu sudebnoy praktiki narsudov Stalingradskoy oblasti po delam osobogo proizvodstva - o vzyskanii shtrafov, nalozhennykh v administrativnom poryadke za 1 polugodie $1941 \mathrm{~g}$. yanvar - fevral $1942 \mathrm{~g}$. [Report on the Study of Judicial Practice of People's Courts of the Stalingrad Region on Special Proceedings for the Recovery of Fines Imposed in Administrative Proceedings for the 1st Half of 1941 - January-February 1942]. Gosudarstvennyy arkhiv Volgogradskoy oblasti [State Archive of the Volgograd Region], F. 6332, Op. 1, D. 4.1601.

7. Dokladnaya zapiska № 188 ot 16.05 .1942 o poluchenii prikaza za kontrolem ispolneniya prigovorov po delam lits, osuzhdennykh za samovolnyy ukhod s predpriyatiy i uchrezhdeniy (po prikazu NKYu SSSR № 05 ot 06.03.1942) [Memorandum no. 188 of May 16, 1942 on Receipt of the Instruction for Enforcement of Sentences in Cases of Persons Convicted of Unauthorized Departure from the Enterprises and Institutions (by the Order of People's Commissariat for Justice of the USSR no. 05 of March 6, 1942)]. Gosudarstvennyy arkhiv Volgogradskoy oblasti [State Archive of the Volgograd Region], F. 6332, Op. 1, D. 4. 1601.

8. Dokladnaya zapiska ispolnyayushchego obyazannosti nachalnika UNKYu S.Z. Levina v NKYu RSFSR o sostoyanii raboty UNKYu ot 20.12.1942 [Memorandum of Acting Chief of Department of People's Commissariat for Justice S.Z. Levin to People's Commissariat for Justice of the RSFSR on the Status of Work ofDepartment of People's Commissariat for Justice of December 20, 1942]. Gosudarstvennyy arkhiv Volgogradskoy oblasti [State Archive of the Volgograd Region], F. 6332, Op. 1, D. 4. 1601.

9. Dokladnaya zapiska starshego revizora NKYu RSFSR E. Grina za № 303 ot 01.07.1942 v Stalingradskiy obkom VKP(b) t. Lyapinu o rezultatakh proverki raboty sudebnykh organov Stalingradskoy oblasti v 1942 g. [Memorandum of Senior Auditor of People's Commissariat for Justice of the RSFSR E. Grin no. 303 of July 1, 1942 to the Stalingrad Regional Committee of the All-Union Communist Party (Bolsheviks) to Comrade Lyapia on the Results of Monitoring the Work of the Judiciary in the Stalingrad Region in 1942]. 
Gosudarstvennyy arkhiv Volgogradskoy oblasti [State Archive of the Volgograd Region], F. 6332, Op. 1, D. 4.1601 .

10. Informatsionnoe pismo NKYu RSFSR № 1 -2/sd ot 12.09.1941 o rabote sudov $\mathrm{V}$ voennoe vremya [Informational Letter of People's Commissariat for Justice of the RSFSR no. 1 -2/sd of September 12, 1941 about the Activity of Courts in Wartime]. Gosudarstvennyy arkhiv Volgogradskoy oblasti [State Archive of the Volgograd Region], F. 6332, Op. 1, D. 2. 2401.

11. Informatsionnoe soobshchenie Upolnomochennomu KPK po Stalingradskoy oblasti t. Yagodkinu ot vremennoispolnyayushchego obyazannosti nachalnika UNKYu N.A. Mironova ot 04.12.1942 [Informational Announcement to the Authorised Official of Central Control Commission in the Stalingrad region Comrade Yagodkin from Acting Chief of Department of People's Commissariat for Justice N.A. Mironov of December 4, 1942]. Gosudarstvennyy arkhiv Volgogradskoy oblasti [State Archive of the Volgograd Region], F. 6332, Op. 1, D. 4. 1601.

12. Obobshchenie praktiki oblsuda za oktyabr noyabr 1942 g. za № 437 ot 04.12.1942 [Summarizing the Practice of the Regional Court for October - November, 1942 no. 437 of December 4, 1942]. Gosudarstvennyy arkhiv Volgogradskoy oblasti [State Archive of the Volgograd Region], F. 6332, Op. 1, D. 4. 1601.

13. Pismo NKYu SSSR Rychkova za № 028s ot 15.07.1941 o sokrashchenii shtatov v svyazi s voennoy obstanovkoy [Letter of the People's Commissariat for Justice of the USSR Rychkov no. 028c of July 15, 1941 about Downsizing in Connection with the Military Situation]. Gosudarstvennyy arkhiv Volgogradskoy oblasti [State Archive of the Volgograd Region], F. 6332, Op. 1, D. 2.2401.

14. Postanovlenie Stalingradskogo oblastnogo ispolnitelnogo komiteta Soveta narodnykh deputatov ob obrazovanii Upravleniya yustitsii NKYu RSFSR [The Resolution of the Stalingrad Regional Executive Committee Council of People's Deputies on the Formation of the Department of People's Commissariat for Justice of the RSFSR]. Gosudarstvennyy arkhiv Volgogradskoy oblasti [State Archive of the Volgograd Region], F. 2115, Op. 1, D. 247, L. 15.

15. Prikaz NKYu RSFSR № 5/S ot 07.07. 1941 g. o neotlozhnykh meropriyatiya organov NKYu v voennoe vremya [Order of People's Commissariat for Justice of the RSFSR no. 5/S of July 7, 1941 on Immediate Measures of Authorities of People's Commissariat for Justice in Wartime]. Gosudarstvennyy arkhiv Volgogradskoy oblasti [State Archive of the Volgograd Region], F. 6332, Op. 1, D. 2. 2401.

16. Prikaz NKYu SSSR № 030s ot 17 iyulya $1941 \mathrm{~g}$. o podsudnosti del [Order of People's Commissariat for Justice of the USSR no. 030c of July 17, 1941 on the Jurisdiction of Cases]. Gosudarstvennyy arkhiv Volgogradskoy oblasti [State Archive of the Volgograd Region], F. 6332, Op. 1, D. 2. 2401.

17. Prikaz Prokurora i NKYu RSFSR №10/7s ot 04.08.1941 ob ugolovnoy otvetstvennosti za nevypolnenie trebovaniy organov gosudarstvennoy saninspektsii [Order of the Prosecutor and People's Commissariat for Justice of the RSFSR no. 10/7 of August 4, 1941 about Criminal Liability for Failure to Comply with the State Sanitary Inspectorate]. Gosudarstvennyy arkhiv Volgogradskoy oblasti [State Archive of the Volgograd Region], F. 6332, Op. 1, D. 2. 2401.

18. Razyasnitelnoe pismo № 023 NKYu SSSR Rychkova na mesta o delakh sudov v svyazi s evakuatsiey ot 08.07.1941 [Explanatory Letter no. 023 of People's Commissariat for Justice of the USSR Rychkov on Cases of the Courts due to the Evacuation of July 8, 1941]. Gosudarstvennyy arkhiv Volgogradskoy oblasti [State Archive of the Volgograd Region], F. 6332, Op. 1, D. 2. 2401.

19. Razyasnitelnoe pismo NKYu SSSR za № 16-A ot 19.09.1941 o nedostatkakh v rabote prezidiumov kollegiy advokatov [Explanatory Letter of People's Commissariat for Justice of the USSR no. 16-A of September 19, 1941 about the Shortcomings in the Work of the Presidium of the Collegiums of Advocates]. Gosudarstvennyy arkhiv Volgogradskoy oblasti [State Archive of the Volgograd Region], F. 6332, Op. 1, D. 2.2401 .

20. Redkina O.Yu. Izuchenie istorii Stalingradskoy bitvy i vosstanovleniya Stalingrada v Volgogradskom gosudarstvennom universitete [Studying the History of the Battle of Stalingrad and Restoration of Stalingrad at the Volgograd State University]. Vestnik Volgogradskogo gosudarstvennogo universiteta. Seriya 4. Istoriya. Regionovedenie. Mezhdunarodnye otnosheniya [Science Journal of Volgograd State University. History. Area Studies. International Relations], 2013, no. 1 (23), pp. 143-148. DOI: http:// dx.doi.org/10.15688/jvolsu4.2013.1.23.

21. Spetsdonesenie № $1 / \mathrm{P} / 352$ ot 08.09 .1942 [Special Report no. 1/P/352 of September 8, 1942]. Gosudarstvennyy arkhiv Volgogradskoy oblasti [State Archive of the Volgograd Region], F. 6332, Op. 1, D. 4.1601 .

22. Spetsdoneseniya UNKYu po Stalingradskoy oblasti v NKYu RSFSR so statisticheskoy otchetnostyu [Special Reports of Department of People's Commissariat for Justice in Stalingrad region to People's Comissariat for Justice of the RSFSR with the Statistical Report]. Gosudarstvennyy arkhiv Volgogradskoy oblasti [State Archive of the Volgograd Region], F. 6332, Op. 1, D. 2. 2401. 


\section{Information about the Authors}

Svetlana Yu. Pishchulina, Candidate of Science (History), Head of Department of Theory and History of State and Law, International Law Institute (Volzhsky Branch), Bolshevistskaya St., 7, 404106 Volzhsky, Russian Federation, supishulina@mail.ru, https://orcid.org/0000-0003-0814-1038

Marina L. Davydova, Doctor of Sciences (Jurisprudence), Professor, Head of Department of Constitutional and Municipal Law, Volgograd State University, Prosp. Universitetsky, 100, 400062 Volgograd, Russian Federation, kmp@volsu.ru, https://orcid.org/0000-0001-8392-9592

Aleksandr A. Vilkov, Doctor of Sciences (Politics), Professor, Head of Department of Political Sciences, Saratov State University named after N.G. Chernyshevsky, Astrakhanskaya St., 83, 410012 Saratov, Russian Federation, Polit_jurid@info.sgu.ru, https://orcid.org/0000-0003-4277-0372

\section{Информация об авторах}

Светлана Юрьевна Пищулина, кандидат исторических наук, заведующая кафедрой теории и истории государства и права, Международный юридический институт (Волжский филиал), ул. Большевистская, 7, 404106 г. Волжский, Российская Федерация, supishulina@mail.ru, https:// orcid.org/0000-0003-0814-1038

Марина Леонидовна Давыдова, доктор юридических наук, профессор, заведующая кафедрой конституционного и муниципального права, Волгоградский государственный университет, просп. Университетский, 100, 400062 г. Волгоград, Российская Федерация, kmp@volsu.ru, https:// orcid.org/0000-0001-8392-9592

Александр Алексеевич Вилков, доктор политических наук, профессор, заведующий кафедрой политических наук, Саратовский государственный университет им. Н.Г. Чернышевского, ул. Астраханская, 83, 410012 г. Саратов, Российская Федерация, Polit_jurid@info.sgu.ru, https:// orcid.org/0000-0003-4277-0372 